\title{
MANAJEMEN PERSEDIAAN BARANG RUMAH TANGGA (BRT) RSUD KOTA DUMAI
}

\author{
Nanda Fahmy ${ }^{(1)}$, Surya \\ Indrawan $^{(2)}$ Soni Fajar \\ Mahmud $^{(3)}$ \\ ${ }^{1)}$ Program Studi Teknik Industri, Sekolah \\ Tinggi Teknologi Dumai \\ Jl. Utama Karya Bukit Batrem II \\ Email: nandafahmy06@gmail.com; \\ suryaindrawan03@gmail.com; \\ Sfajarmahmud@gmail.com
}

\begin{abstract}
ABSTRAK
Salah satu instansi yang menangani dibidang kesehatan adalah rumah sakit, rumah sakit adalah tempat dimana orang atau masyarakat berkonsultasi tentang kesehatan atau mencari solusi tentang penyakit yang dideritanya. Untuk membantu kelancaran pelayanan di rumah sakit fungsi bagian support juga sangat berperan menentukan kelangsungan kegiatan operasional rumah sakit, salah satunya adalah bagian pengadaan barang atau bagian logistik. Menurut survey sementara Instalasi Aset dan Logistik RSUD Kota Dumai terlihat mengalami adanya kekosongan barang dan penumpukan barang yang terjadi pada bagian logistik seperti barang rumah tangga (BRT) sehingga ketika user membutuhkan suatu barang cukup penting untuk menunjang operasional bagian manajemen rumah sakit dan pada saat itu pula gudang logistik mengalami stockout. Penulis melakukan penelitian menggunakan peramalan dan metode Economic Order Quantity (EOQ) untuk mengetahui persediaan yang optimal untuk menjaga tidak kehabisan stok barang rumah tangga (BRT) pada RSUD Kota Dumai. Berdasarkan hasil yang telah didapat, maka dapat disimpulkan bahwa total persediaan satu periode ke depan untuk masing-masing barang rumah tangga (BRT) menggunakan peramalan Exponential Smoothing yaitu: Hand Soap Refill sebanyak 162 item, Rumah Pisau Cukur sebanyak 68 item, Plastik Sedang sebanyak 169 item, Tissue Gulung Biasa sebanyak 180 item dan Tissue Hand Towel sebanyak 92 item.
\end{abstract}

Kata kunci: Barang Rumah Tangga, Economic Order Quantity, Exponential Smoothing, Rumah Sakit.

\section{ABSTRACT}

One of the agencies that deal with the health sector is a hospital, a hospital is a place where people or the community consult about health or find solutions about their illness. To help smooth services in hospitals, the support function also plays a very important role in determining the continuity of hospital operational activities, one of which is the procurement of goods or logistics department. According to the temporary survey, the Asset and Logistics Installation of the Dumai City Hospital was seen to experience a vacancy of goods and the accumulation of goods that occurred in the logistics section such as household goods (BRT) so that when the user needed an item it was quite important to support the operations of the hospital management department and at that time also logistics warehouse experiencing stockout. The author conducted a study using forecasting and the Economic Order Quantity (EOQ) method to find out the optimal inventory to keep the household goods (BRT) out of stock at the Dumai City Hospital. Based on the results obtained, it can be concluded that the total inventory for the next period for each household item (BRT) uses Exponential Smoothing forecasting, namely: Hand Soap Refill as many as 162 items, Razor House as many as 68 items, Medium Plastics as many as 169 items, 180 items of Ordinary 
Keywords: Economic Order Quantity, Exponential Smoothing, Hospital, Household Goods.

\section{Pendahuluan}

Kesehatan merupakan salah satu kebutuhan pokok dan dasar manusia disamping pangan, pemukiman dan pendidikan, karena hanya dalam keadaan sehat manusia dapat hidup, tumbuh dan berkarya lebih baik (Agoes \& Jacob, 1996). Maka dari pada itu kesehatan cukup penting bagi kelangsungan kehidupan manusia. Salah satu instansi yang menangani dibidang kesehatan adalah rumah sakit, rumah sakit adalah tempat dimana orang atau masyarakat berkonsultasi tentang kesehatan atau mencari solusi tentang penyakit yang dideritanya. secara garis besar menurut World Health Organization, Pengertian Rumah Sakit adalah suatu bagian dari organisasi medis dan sosial yang mempunyai fungsi untuk memberikan pelayanan kesehatan lengkap kepada masyarakat, baik kuratif maupun preventif pelayanan keluarnya menjangkau keluarga dan lingkungan rumah.

Untuk membantu kelancaran pelayanan di rumah sakit fungsi bagian support juga sangat berperan menentukan kelangsungan kegiatan operasional rumah sakit, salah satunya adalah bagian pengadaan barang atau bagian logistik. Pengadaan Barang merupakan bagian dari siklus logistik. Pengadaan merupakan segala kegiatan dan usaha untuk menambah dan memenuhi kebutuhan barang dan jasa berdasarkan peraturan yang berlaku dengan menciptakan sesuatu yang tadinya tidak ada menjadi ada. Untuk memenuhi kebutuhan user, bagian logistik melakukan pengadaan barang. Pengadaan barang pada RSUD Kota Dumai menggunakan dua metode pembelian yaitu dengan menggunakan metode pemesanan barang terlebih dahulu dengan menggunkan atau membuat Surat Pemesanan (PO) terlebih dahulu sebelum melakukan pembelian barang dan barang-barang yang dibeli dengan menggunakan metode ini adalah obat- obatan serta dan alat kesehatan serta barang cetakan. Selain dengan menggunakan metode pemesanan, RSUD Kota Dumai juga melakukan pengadaan barang dengan menggunakan metode pembelian cash and carry yang di mana barang-barang yang di beli adalah barang yang harga atau biaya yang akan di keluarkan untuk mendapatkan barang tersebut sudah banyak diketahui oleh orang lain. Contoh barang yang sering di beli dengan menggunakan metode pembelian cash and carry adalah barang-barang yang berjenis barang rumah tangga (BRT).

Menurut survey sementara Instalasi Aset dan Logistik RSUD Kota Dumai terlihat mengalami adanya kekosongan barang dan penumpukan barang yang terjadi pada bagian logistik seperti barang rumah tangga (BRT) sehingga ketika user membutuhkan suatu barang cukup penting seperti Hand Soap Refille, Rumah Pisau Cukur, Plastik Sedang, Tissue Gulung Biasa dan Tisue Hand Towel adalah barang rumah tangga (BRT) yang paling banyak digunakan di RSUD Kota Dumai untuk menunjang operasional bagian manajemen rumah sakit dan pada saat itu pula gudang logistik mengalami stockout sehingga akan menyebabkan operasional rumah sakit sedikit terganggu dikarenaka barang yang dibutuhkan oleh user tidak tersedia di gudang logistik, sedangkan barang yang mungkin kurang dibutuhkan user mengalami penumpukan di gudang logistic. 
Oleh sebab itu perlu dilakukan perhitungan pembelian dengan metode EOQ (Economic Order Quantity) agar pengadaan atau pembelian barang rumah tangga (BRT) di RSUD Kota Dumai sesuai dengan kebutuhan user.

\section{Metode Penelitian}

Penelitian ini dilakukan pada Instalasi Aset dan Logistik Rumah Sakit Umum Daerah (RSUD) Kota Dumai yang berada di Jl. Tanjung Jati No.4, Kelurahan Buluh Kasap Kecamatan Dumai Timur Kota Dumai. Populasi dalam penelitian ini adalah semua jenis barang rumah tangga (BRT) yang ada pada Instalasi Aset dan Logistik RSUD Kota sebanyak 56 item. Berdasarkan jumlah populasi, maka sampel yang diambil dalam penelitian ini adalah barang rumah tangga (BRT) yang pemakaiannya terbanyak di RSUD Kota Dumai yaitu Handsoap Refille, Rumah Pisau Cukur, Plastik Sedang, Tissue Gulung Biasa, Tissue Hand. Data-data yang dikumpulkan adalah data sekunder, yaitu data yang sudah diolah atau disajikan oleh pihak RSUD Kota Dumai yang terdiri dari: data jenis-jenis barang rumah tangga (BRT) di RSUD Kota Dumai, jumlah permintaan barang rumah tangga (BRT) dalam waktu 1 tahun terakhir sebelumnya,biaya pesan dan biaya simpan di RSUD Kota. Dalam penelitian ini, pengolahan data dilakukan menggunakan Microsoft Excel. Langkah-langkah yang dilakukan dalam menganalisis data, yaitu meramalkan jumlah permintaan obat berdasarkan data permintaan barang rumah tangga (BRT) sebelumnya, lalu menghitung jumlah persediaan dengan metode EOQ.

\section{Hasil dan Pembahasan}

Data pembelian barang rumah tangga yang sering digunakan di RSUD Kota Dumai ada 5 macam barang, yaitu Hand soap refille, Rumah Pisau Cukur, Plastik Sedang, Tissue Gulung Biasa dan Tissue Hand Towel. Data pembelian barang rumah tangga di Instalsi Aset dan Logistik RSUD Kota Dumai pada bulan Juni 2020 sampai bulan Mei 2021 dapat dilihat pada Tabel 1.

Tabel 1. Data Pembelian Barang Rumah tangga di Instalasi Aset dan Logistik RSUD Kota Dumai

\begin{tabular}{|c|c|c|r|r|r|r|r|r|r|r|}
\hline \multirow{2}{*}{ Bulan } & \multicolumn{2}{|c|}{$\begin{array}{c}\text { Handsoap } \\
\text { Refille }\end{array}$} & \multicolumn{2}{c|}{ Pisau Cukur } & \multicolumn{2}{c|}{ Plastik Sedang } & \multicolumn{2}{c|}{$\begin{array}{c}\text { Tissue Gulung } \\
\text { Biasa }\end{array}$} & \multicolumn{2}{c|}{$\begin{array}{c}\text { Tissue Hand } \\
\text { Towel }\end{array}$} \\
\cline { 2 - 12 } & $\begin{array}{c}\text { Tahun } \\
2020\end{array}$ & $\begin{array}{c}\text { Tahun } \\
2021\end{array}$ & $\begin{array}{c}\text { Tahun } \\
2020\end{array}$ & $\begin{array}{c}\text { Tahun } \\
2021\end{array}$ & $\begin{array}{c}\text { Tahun } \\
2020\end{array}$ & $\begin{array}{c}\text { Tahun } \\
2021\end{array}$ & $\begin{array}{c}\text { Tahun } \\
2020\end{array}$ & $\begin{array}{c}\text { Tahun } \\
2021\end{array}$ & $\begin{array}{c}\text { Tahun } \\
2020\end{array}$ & $\begin{array}{c}\text { Tahun } \\
2021\end{array}$ \\
\hline Jan & & 280 & & 40 & & 160 & & 240 & & 80 \\
\hline Feb & & 250 & & 28 & & 160 & & 240 & & 80 \\
\hline Mar & & 140 & & 60 & & 160 & & 180 & & 96 \\
\hline Apr & & 140 & & 60 & & 160 & & 180 & & 96 \\
\hline Mei & & 140 & & 40 & & 185 & & 180 & & 96 \\
\hline Jun & 160 & & 30 & & 180 & & 150 & & 72 & \\
\hline Jul & 138 & & 60 & & 180 & & 180 & & 96 & \\
\hline Agt & 145 & & 60 & & 180 & & 150 & & 96 & \\
\hline Sep & 145 & & 60 & & 155 & & 150 & & 96 & \\
\hline Okt & 144 & & 96 & & 85 & & 130 & & 96 & \\
\hline Nov & 130 & & 96 & & 180 & & 130 & & 96 & \\
\hline Des & 113 & & 84 & & 240 & & 130 & & 96 & \\
\hline
\end{tabular}


Analisis dan Evaluasi hasil perhitungan peramalan persediaan untuk barang rumah tangga di Instalsi Aset dan Logistik RSUD Kota Dumai dapat dilihat pada Tabel 2, 3, 4, 5 , dan 6 .

Tabel 2. Perbandingan Hasil Peramalan Perencanaan Persediaan hand soap refill 1 berdasarkan Tiga Model Peramalan

\begin{tabular}{|c|c|c|c|c|}
\hline No & Deskripsi & Model MA(3) & $\begin{array}{c}\text { Model } \\
\text { WMA(3) }\end{array}$ & $\begin{array}{c}\text { Model ES } \\
(\alpha=0,2)\end{array}$ \\
\hline 1 & $\begin{array}{l}\text { Nilai ramalan } \\
\text { permintaan hand } \\
\text { soap refill untuk } \\
\text { periode bulan } \\
\text { Juni } 2021\end{array}$ & 140 item & 140 item & 162 item \\
\hline 2 & $\begin{array}{l}\text { Nilai-nilai } \\
\text { tracking signal }\end{array}$ & $\begin{array}{l}\text { Bervariasi - } \\
1,7 \text { sampai - } \\
4,2\end{array}$ & $\begin{array}{l}\text { Bervariasi } 0,6 \\
\text { sampai } 3,7\end{array}$ & $\begin{array}{l}\text { Bervariasi } 0,8 \\
\text { sampai } 4,0\end{array}$ \\
\hline 3 & $\begin{array}{l}\text { Tebaran nilai-nilai } \\
\text { tracking signal } \\
\text { dalam peta kontrol }\end{array}$ & $\begin{array}{l}\text { Nilai tracking } \\
\text { signal berada } \\
\text { di luar } \\
\text { batas-batas } \\
\text { pengendalian } \\
\text { peta kontrol. } \\
\text { Nilai tracking } \\
\text { signal ada yg } \\
\text { negative. }\end{array}$ & $\begin{array}{l}\text { Nilai tracking } \\
\text { signal berada } \\
\text { di luar } \\
\text { batas-batas } \\
\text { pengendalian } \\
\text { peta kontrol. } \\
\text { Nilai tracking } \\
\text { signal } \\
\text { semuanya } \\
\text { positif. }\end{array}$ & $\begin{array}{l}\text { Semua nilai } \\
\text { tracking } \\
\text { signal berada } \\
\text { dalam } \\
\text { batas-batas } \\
\text { pengendalian } \\
\text { peta kontrol. } \\
\text { Nilai tracking } \\
\text { signal positif } \\
\text { seimbang } \\
\text { dengan nilai- } \\
\text { nilai tracking } \\
\text { signal negatif } \\
\end{array}$ \\
\hline 4 & Nilai RSFE & -2 & -14 & 16 \\
\hline 5 & Keputusan & $\begin{array}{l}\text { Menolak } \\
\text { model MA(3) }\end{array}$ & $\begin{array}{l}\text { Menerima } \\
\text { model } \\
\mathrm{WMA}(3) \\
\end{array}$ & $\begin{array}{l}\text { Menerima } \\
\text { model ES }(\alpha= \\
0,9)\end{array}$ \\
\hline
\end{tabular}

Tabel 3. Perbandingan Hasil Peramalan Perencanaan Persediaan Rumah Pisau Cukur berdasarkan Tiga Model Peramalan

\begin{tabular}{|c|l|l|l|l|}
\hline No & \multicolumn{1}{|c|}{ Deskripsi } & Model MA(3) & Model WMA(3) & $\begin{array}{l}\text { Model ES } \\
(\alpha=0,2)\end{array}$ \\
\hline 1 & $\begin{array}{l}\text { Nilai ramalan } \\
\text { permintaan rumah } \\
\text { pisau cukur } \\
\text { untuk periode } \\
\text { bulan Juni 2021 }\end{array}$ & 53 item & 57 item & 68 item \\
\hline 2 & $\begin{array}{l}\text { Nilai-nilai } \text { tracking } \\
\text { signal }\end{array}$ & $\begin{array}{l}\text { Bervariasi 0,2 } \\
\text { sampai 1,7 }\end{array}$ & $\begin{array}{l}\text { Bervariasi 0,1 } \\
\text { sampai 1,8 }\end{array}$ & $\begin{array}{l}\text { Bervariasi 0,1 } \\
\text { sampai 2,2 }\end{array}$ \\
\hline 3 & $\begin{array}{l}\text { Tebaran nilai-nilai } \\
\text { tracking signal } \\
\text { dalam peta kontrol }\end{array}$ & $\begin{array}{l}\text { Nilai tracking } \\
\text { signal berada di } \\
\text { luar } \\
\text { batas-batas } \\
\text { pengendalian } \\
\text { peta kontrol. } \\
\text { Nilai tracking } \\
\text { signal semuanya } \\
\text { positif. }\end{array}$ & $\begin{array}{l}\text { Nilai tracking } \\
\text { signal berada di } \\
\text { luar } \\
\text { batas-batas } \\
\text { pengendalian } \\
\text { peta kontrol. } \\
\text { Nilai tracking } \\
\text { signal } \\
\text { semuanya } \\
\text { positif. }\end{array}$ & $\begin{array}{l}\text { Semua nilai } \\
\text { tracking } \\
\text { signal berada } \\
\text { dalam } \\
\text { batas-batas } \\
\text { pengendalian } \\
\text { peta kontrol. } \\
\text { Nilai tracking } \\
\text { signal positif } \\
\text { seimbang } \\
\text { dengan nilai- }\end{array}$ \\
\hline
\end{tabular}




\begin{tabular}{|c|c|c|c|c|}
\hline & & & & $\begin{array}{l}\text { nilai tracking } \\
\text { signal negatif }\end{array}$ \\
\hline 4 & Nilai RSFE & 80 & -5 & -9 \\
\hline 5 & Keputusan & $\begin{array}{l}\text { Menerima } \\
\text { model MA(3), } \\
\text { tetapi Peramalan } \\
1 \text { tidak dapat } \\
\text { diterima, jadi } \\
\text { Model MA } 3 \\
\text { Tidak bisa } \\
\text { diterima. }\end{array}$ & $\begin{array}{l}\text { Menerima } \\
\text { model WMA(3) }\end{array}$ & $\begin{array}{l}\text { Menerima } \\
\text { model ES }(\alpha= \\
0,2)\end{array}$ \\
\hline
\end{tabular}

Tabel 4. Perbandingan Hasil Peramalan Perencanaan Persediaan plastik sedang berdasarkan Tiga Model Peramalan

\begin{tabular}{|c|c|c|c|c|}
\hline No & Deskripsi & Model MA(5) & Model WMA(5) & $\begin{array}{l}\text { Model ES } \\
(\alpha=0,2)\end{array}$ \\
\hline 1 & $\begin{array}{l}\text { Nilai ramalan } \\
\text { permintaan plastik } \\
\text { sedang untuk } \\
\text { periode bulan Juni } \\
2021\end{array}$ & 176 item & 20 item & 169 item \\
\hline 2 & $\begin{array}{l}\text { Nilai-nilai tracking } \\
\text { signal }\end{array}$ & $\begin{array}{l}\text { Bervariasi } 0,1 \\
\text { sampai } 1,3\end{array}$ & $\begin{array}{l}\text { Bervariasi } 0,8 \\
\text { sampai } 1,2\end{array}$ & $\begin{array}{l}\text { Bervariasi } 0,3 \\
\text { sampai } 3,3\end{array}$ \\
\hline 3 & $\begin{array}{l}\text { Tebaran nilai-nilai } \\
\text { tracking signal } \\
\text { dalam peta kontrol }\end{array}$ & $\begin{array}{l}\text { Nilai tracking } \\
\text { signal berada di } \\
\text { luar } \\
\text { batas-batas } \\
\text { pengendalian } \\
\text { peta kontrol. } \\
\text { Nilai tracking } \\
\text { signal semuanya } \\
\text { positif. }\end{array}$ & $\begin{array}{l}\text { Nilai tracking } \\
\text { signal berada di } \\
\text { luar } \\
\text { batas-batas } \\
\text { pengendalian } \\
\text { peta kontrol. } \\
\text { Nilai tracking } \\
\text { signal } \\
\text { semuanya } \\
\text { positif. }\end{array}$ & $\begin{array}{l}\text { Semua nilai } \\
\text { tracking } \\
\text { signal berada } \\
\text { dalam } \\
\text { batas-batas } \\
\text { pengendalian } \\
\text { peta kontrol. } \\
\text { Nilai tracking } \\
\text { signal positif } \\
\text { seimbang } \\
\text { dengan nilai- } \\
\text { nilai tracking } \\
\text { signal negatif } \\
\end{array}$ \\
\hline 4 & Nilai RSFE & 117 & 1098 & 27 \\
\hline 5 & Keputusan & $\begin{array}{l}\text { Menerima } \\
\text { model MA(5), } \\
\text { Menerima } \\
\text { model MA(3), } \\
\text { tetapi Peramalan } \\
1 \text { tidak dapat } \\
\text { diterima, jadi } \\
\text { Model MA } 3 \\
\text { Tidak bisa } \\
\text { diterima. }\end{array}$ & $\begin{array}{l}\text { Menolak model } \\
\text { WMA(5) }\end{array}$ & $\begin{array}{c}\text { Menerima } \\
\text { model ES }(\alpha= \\
0,2)\end{array}$ \\
\hline
\end{tabular}


Tabel 5. Perbandingan Hasil Peramalan Perencanaan Persediaan Tisu Gulung Biasa berdasarkan Tiga

\begin{tabular}{|c|c|c|c|c|}
\hline No & Deskripsi & Model MA(5) & Model WMA(5) & $\begin{array}{c}\text { Model ES } \\
(\alpha=0,2)\end{array}$ \\
\hline 1 & $\begin{array}{l}\text { Nilai ramalan } \\
\text { permintaan tisu } \\
\text { gulung biasa untuk } \\
\text { periode bulan Juni } \\
2021\end{array}$ & 204 item & 27 item & 180 item \\
\hline 2 & $\begin{array}{l}\text { Nilai-nilai tracking } \\
\text { signal }\end{array}$ & $\begin{array}{l}\text { Bervariasi } 0,1 \\
\text { sampai } 2,2\end{array}$ & $\begin{array}{l}\text { Bervariasi } 1,0 \\
\text { sampai } 1,5\end{array}$ & $\begin{array}{l}\text { Bervariasi } 0,0 \\
\text { sampai } 3,1\end{array}$ \\
\hline 3 & $\begin{array}{l}\text { Tebaran nilai-nilai } \\
\text { tracking signal } \\
\text { dalam peta kontrol }\end{array}$ & $\begin{array}{l}\text { Nilai tracking } \\
\text { signal berada di } \\
\text { luar } \\
\text { batas-batas } \\
\text { pengendalian } \\
\text { peta kontrol. } \\
\text { Nilai tracking } \\
\text { signal semuanya } \\
\text { positif. }\end{array}$ & $\begin{array}{l}\text { Nilai tracking } \\
\text { signal berada di } \\
\text { luar } \\
\text { batas-batas } \\
\text { pengendalian } \\
\text { peta kontrol. } \\
\text { Nilai tracking } \\
\text { signal semuanya } \\
\text { positif. }\end{array}$ & $\begin{array}{l}\text { Semua nilai } \\
\text { tracking } \\
\text { signal berada } \\
\text { dalam } \\
\text { batas-batas } \\
\text { pengendalian } \\
\text { peta kontrol. } \\
\text { Nilai tracking } \\
\text { signal positif } \\
\text { seimbang dengan } \\
\text { nilai-nilai } \\
\text { tracking signal } \\
\text { negatif }\end{array}$ \\
\hline 4 & Nilai RSFE & -46 & 1141 & 4 \\
\hline 5 & Keputusan & $\begin{array}{l}\text { Menerima model } \\
\text { MA(5), tetapi } \\
\text { Peramalan } 1 \\
\text { tidak dapat } \\
\text { diterima, jadi } \\
\text { Model MA } 3 \\
\text { Tidak bisa } \\
\text { diterima. }\end{array}$ & $\begin{array}{l}\text { Menerima model } \\
\text { WMA(3) }\end{array}$ & $\begin{array}{c}\text { Menerima model } \\
\text { ES }(\alpha=0,2)\end{array}$ \\
\hline
\end{tabular}

Tabel 6. Perbandingan Hasil Peramalan Perencanaan Persediaan Tisu Hand Towel berdasarkan Tiga Model Peramalan

\begin{tabular}{|c|l|l|l|l|}
\hline No & \multicolumn{1}{|c|}{ Deskripsi } & Model MA(5) & Model WMA(5) & \multicolumn{1}{|c|}{$\begin{array}{l}\text { Model ES } \\
(\alpha=0,2)\end{array}$} \\
\hline 1 & $\begin{array}{l}\text { Nilai ramalan } \\
\text { permintaan tisu hand } \\
\text { towel untuk periode } \\
\text { bulan Juni 2021 }\end{array}$ & 90 item & 11 item & 92 item \\
\hline 2 & $\begin{array}{l}\text { Nilai-nilai tracking } \\
\text { signal }\end{array}$ & $\begin{array}{l}\text { Bervariasi 0,6 } \\
\text { sampai 2,0 }\end{array}$ & $\begin{array}{l}\text { Bervariasi 0,8 } \\
\text { sampai 1,1 }\end{array}$ & $\begin{array}{l}\text { Bervariasi ,0 } \\
\text { sampai 3,2 }\end{array}$ \\
\hline 3 & $\begin{array}{l}\text { Tebaran nilai-nilai } \\
\text { tracking signal dalam } \\
\text { peta kontrol }\end{array}$ & $\begin{array}{l}\text { Nilai tracking } \\
\text { signal berada di } \\
\text { luar } \\
\text { batas-batas } \\
\text { pengendalian peta } \\
\text { kontrol. Nilai } \\
\text { tracking signal } \\
\text { semuanya positif. }\end{array}$ & $\begin{array}{l}\text { Nilai tracking } \\
\text { signal berada di } \\
\text { luar } \\
\text { batas-batas } \\
\text { pengendalian peta } \\
\text { kontrol. Nilai } \\
\text { tracking signal } \\
\text { semuanya positif. }\end{array}$ & $\begin{array}{l}\text { Semua nilai } \\
\text { tracking } \\
\text { signal berada } \\
\text { dalam } \\
\text { batas-batas } \\
\text { pengendalian peta } \\
\text { kontrol. } \\
\text { Nilai tracking } \\
\text { signal positif } \\
\text { seimbang dengan } \\
\text { nilai-nilai } \\
\text { tracking signal } \\
\text { negatif }\end{array}$ \\
\hline
\end{tabular}




\begin{tabular}{|l|l|l|l|r|}
\hline 4 & Nilai RSFE & 0 & 562 & 50 \\
\hline 5 & Keputusan & Menerima model & Menerima model & Menerima model \\
& & MA(5), tetapi & WMA(5) & ES $(\alpha=0,2)$ \\
& & $\begin{array}{l}\text { Peramalan 1 tidak } \\
\text { dapat diterima, }\end{array}$ & & \\
& & jadi Model MA 5 & & \\
& & Tidak bisa & & \\
& & diterima. & & \\
\hline
\end{tabular}

Setelah hasil peramalan persedian barang rumah tangga di dapatkan maka tahap selanjutnya menghitung Economic Order Quantity untuk setiapa barang tersebut.

1. Hand Soap Refill

Hasil peramalan menggunakan model forecast pemulusan eksponensial yang bisa dijadikan perhitungan EOQ karena mempunyai nilai tricking signal yang mendekati nol. Maka didapatkan hasil peramalan untuk bulan Mei 2021 sebesar 160 item. Maka jumlah estimasi kebutuhan jumlah Hand Soap Refill untuk 1 tahun ke depan adalah 160 x $12=1920$ item.

a. Biaya Pembelian (Purchasing Cost/ Tahun $)=\sum$ Kebutuhan $/$ tahun $\mathrm{x}$ Harga

$$
=1920 \mathrm{x} \text { Rp. } 17.500=33.600 .500
$$

b. Biaya Simpan/Unit (Nilai h) = Harga Item/Unit x 20\% = Rp. $17.500 \times 20 \%$

$=$ Rp. 3.500

Nilai k masing-masing Item $=$ Konstanta nilai $\mathrm{x}$ dari total biaya pesan setiap kali pesan

c. Nilai k Hand Soap Refill

$17.500=X+\left(X^{*} 10 \%\right)$

$=\mathrm{X}+0,1 \mathrm{X}$

$=1.1 \mathrm{X}$

Rumus : Total Nilai $\mathrm{k}=$ Total Kebutuhan/ Tahun (D) x Nilai K masing-masing item

d. Total Nilai Hand Soap Refill

$=1920 \times 1.1=2112$

Rumus : Q optimal (EOQ)

e. EOQ Hand Soap Refill

$=\sqrt{\frac{2 X D X k}{h}}$

$=\sqrt{\frac{2 \times 1920 \times 2112}{3.500}}=48,13$ item

$=\frac{\text { Total } \frac{\text { Kebutuhan }}{\text { thn }}}{\text { Qoptimal }(\text { EOQ })}$

$=\frac{1920}{48,13}=39.89 \mathrm{kali}$

Setelah diketahui kuantitas pesanan Q pada tingkat EOQ, melengkapi model ini dibutuhkan penentuan waktu tunggu (lead time) antara waktu pesan sampai barang diterima. Oleh karena itu, perusahaan membutuhkan persediaan pengaman. Besarnya persediaan pengaman bisa ditentukan berdasarkan masa tunggu pesanan melalui persamaan, yaitu:

Lead Time $($ Waktu Pemesanan $) /$ Periode $=\frac{316(\text { hari } \text { ker } j \text { a setahun })}{\text { Frekuensi Pembelian }}$

Lead Time Hand Soap Refill

$=\frac{316}{39.89}=8$ hari

Persediaan pengaman

$$
=\frac{1920}{316} \times 8 \text { hari }=48.60 \text { item }
$$

Dengan demikian, pemesanan kembali yaitu pada kondisi tingkat persediaan pengaman ditambah kuantitas pemesanan pada tingkat EOQ yaitu sebesar $48.6+48.13$ $=97$ item. Selanjutnya menghitung reoder point (ROP) yaitu titik jumlah pemesanan 
kembali atau untuk menentukan berapa batas minimal tingkat persediaan yang harus dipertimbangkan sehingga tidak terjadi kekurangan.

$\mathrm{ROP}=\mathrm{SS}+(\mathrm{d} \times \mathrm{LT})$

$\mathrm{d}=\frac{1920}{316}=6.07$

Maka, $\mathrm{ROP}=6.07+(6.07 \times 8)=54.63$ item

Artinya, RSUD Kota Dumai Instansi Logistikharus melakukan pemesanan hand soap refill pada waktu jumlah persediaan obat tinggal 55 item. Selanjutnya perhitungan untuk maksimum stok adalah sebagai berikut:

Maksimum stok $=\mathrm{EOQ}+\mathrm{SS}+\mathrm{z}$

$\mathrm{z}$ didapat dari kebutuhan selama lead time yaitu:

$\mathrm{z}=\mathrm{LT} \times \frac{\mathrm{D}}{12}=8 \times \frac{1920}{12}=1280$ item

Maka, maksimum stok $=48.13+6.07+1280=1334$ item

Dapat diketahui bahwa jumlah estimasi kebutuhan hand soap refill untuk satu tahun ke depan adalah 1920 item, jumlah maksimum stok sebesar 1334 item, dilakukan pemesanan kembali pada saat jumlah kebutuhan hand soap refill di RSUD Kota Dumai sebanyak 55 item, dan jumlah safety stock sebesar 6 item dengan lead time 8 hari.

2. Rumah Pisau Cukur

Hasil peramalan menggunakan model forecast pemulusan eksponensial untuk bulan Mei 2021 sebesar 68 item. Maka jumlah estimasi kebutuhan jumlah rumah pisau cukur untuk 1 tahun ke depan adalah $68 \times 12=816$ item.

a. Biaya Pembelian (Purchasing Cost/ Tahun) $=\sum$ Kebutuhan/tahun $\mathrm{x}$ Harga

$$
=816 \times \text { Rp. } 7.500=6.120 .000
$$

$$
\text { b. Biaya Simpan/Unit }\left(\text { Nilai h) }=\text { Harga Item/Unit } \times \begin{array}{rl}
20 \% & =\text { Rp. } 7.500 \times 20 \% \\
& =\text { Rp. } 1.500
\end{array}\right.
$$

Nilai $\mathrm{k}$ masing-masing Item $=$ Konstanta nilai $\mathrm{x}$ dari total biaya pesan setiap kali pesan

$$
\text { c. Nilai k Rumah Pisau Cukur } \quad \begin{aligned}
1.500 & =\mathrm{X}+(\mathrm{X} * 10 \%) \\
& =\mathrm{X}+0,1 \mathrm{X} \\
& =1.1 \mathrm{X}
\end{aligned}
$$

Rumus : Total Nilai $\mathrm{k}=$ Total Kebutuhan/ Tahun (D) $\mathrm{x}$ Nilai K masing-masing item

d. Total Nilai Rumah Pisau Cukur

Rumus : Q optimal (EOQ)

e. EOQ Rumah Pisau Cukur

Rumus : Frekuensi Pembelian/Periode

f. Frekuensi pesanan Rumah Pisau Cukur

$$
\begin{aligned}
& =816 \times 1.1=897.6 \\
& =\sqrt{\frac{2 \times D \times k}{h}} \\
& =\sqrt{\frac{2 \times 816 \times 897.6}{1500}}=31.25 \text { item } \\
& =\frac{\text { Total } \frac{\text { Kebutuhan }}{\text { thn }}}{\text { Qoptimal }(\text { EOQ })} \\
& =\frac{816}{31.25}=26.11 \mathrm{kali}
\end{aligned}
$$

Setelah diketahui kuantitas pesanan Q pada tingkat EOQ, melengkapi model ini dibutuhkan penentuan waktu tunggu (lead time) antara waktu pesan sampai barang diterima. Oleh karena itu, perusahaan membutuhkan persediaan pengaman. Besarnya persediaan pengaman bisa ditentukan berdasarkan masa tunggu pesanan melalui persamaan, yaitu: 
Lead Time (Waktu Pemesanan)/Periode $=\frac{316(\text { hari } \text { ker } j \text { a setahun })}{316 \text { (rekensi Pembelian }}$

Lead Time Rumah Pisau Cukur $\quad=\frac{316}{26.11}=12$ hari

Persediaan pengaman $=\frac{816}{316} \times 12 \mathrm{hari}=30.98$ item

Dengan demikian, pemesanan kembali yaitu pada kondisi tingkat persediaan pengaman ditambah kuantitas pemesanan pada tingkat EOQ yaitu sebesar $30.98+31.25$ = 62 item. Selanjutnya menghitung reoder point (ROP) yaitu titik jumlah pemesanan kembali atau untuk menentukan berapa batas minimal tingkat persediaan yang harus dipertimbangkan sehingga tidak terjadi kekurangan.

$\mathrm{ROP}=\mathrm{SS}+(\mathrm{d} \times \mathrm{LT})$

$\mathrm{d}=\frac{816}{316}=2.58$

Maka, ROP $=2.58+(2.58 \times 12)=33.54$ item

Artinya, RSUD Kota Dumai Instansi Logistik harus melakukan pemesanan rumah pisau cukur pada waktu jumlah persediaan logistik tinggal 34 item. Selanjutnya perhitungan untuk maksimum stok adalah sebagai berikut:

Maksimum stok $=\mathrm{EOQ}+\mathrm{SS}+\mathrm{z}$

$\mathrm{z}$ didapat dari kebutuhan selama lead time yaitu:

$\mathrm{z}=\mathrm{LT} \times \frac{\mathrm{D}}{12}=12 \times \frac{816}{12}=816$ item

Maka, maksimum stok $=31.25+2.58+816=849,8$ item

Dapat diketahui bahwa jumlah estimasi kebutuhan rumah pisau cukur untuk satu tahun ke depan adalah 816 item, jumlah maksimum stok sebesar 850 item, dilakukan pemesanan kembali pada saat jumlah kebutuhan rumah pisau cukur di RSUD Kota Dumai sebanyak 62 item, dan jumlah safety stock sebesar 3 item dengan lead time 12 hari.

3. Plastik Sedang

Hasil peramalan menggunakan model forecast pemulusan eksponensial untuk bulan Mei 2021 sebesar 169 item. Maka jumlah estimasi kebutuhan jumlah plastik sedang untuk 1 tahun ke depan adalah 169 x $12=2028$ item.

a. Biaya Pembelian (Purchasing Cost/ Tahun) $=\sum$ Kebutuhan $/$ tahun $\mathrm{x}$ Harga

$=2028$ x Rp. $28.500=57.798 .000$

b. Biaya Simpan/Unit $($ Nilai h $)=$ Harga Item/Unit x $20 \%=$ Rp. $28.500 \times 20 \%$ $=$ Rp. 5.700

Nilai $\mathrm{k}$ masing-masing Item $=$ Konstanta nilai $\mathrm{x}$ dari total biaya pesan setiap kali pesan
c. Nilai k Plastik Sedang
$5.700=\mathrm{X}+\left(\mathrm{X}^{*} 10 \%\right)$
$=\mathrm{X}+0,1 \mathrm{X}$
$=1.1 \mathrm{X}$

Rumus : Total Nilai $\mathrm{k}=$ Total Kebutuhan/ Tahun (D) x Nilai K masing-masing item

d. Total Nilai Plastik Sedang

Rumus : Q optimal (EOQ)

e. EOQ Plastik Sedang

Rumus : Frekuensi Pembelian/Periode

$$
=2028 \times 1.1=2230
$$

$=\sqrt{\frac{2 X D X k}{h}}$

$=\sqrt{\frac{2 \times 2028 \times 2230}{5700}}=39.83$ item

$=\frac{\text { Total } \frac{\text { Kebutuhan }}{\text { thn }}}{\text { Qoptimal (EOQ) }}$ 
f. Frekuensi pesanan Plastik Sedang $\quad=\frac{2028}{39.83}=50.91 \mathrm{kali}$

Setelah diketahui kuantitas pesanan Q pada tingkat EOQ, melengkapi model ini dibutuhkan penentuan waktu tunggu (lead time) antara waktu pesan sampai barang diterima. Oleh karena itu, perusahaan membutuhkan persediaan pengaman. Besarnya persediaan pengaman bisa ditentukan berdasarkan masa tunggu pesanan melalui persamaan, yaitu:

$$
\begin{array}{ll}
\text { Lead Time }(\text { Waktu Pemesanan }) / \text { Periode } & =\frac{316(\text { hari } \text { ker } j \text { a setahun })}{\text { Frekuensi Pembelian }} \\
\text { Lead Time Plastik Sedang } & =\frac{316}{50.91}=6 \text { hari }
\end{array}
$$

Persediaan pengaman $=\frac{2028}{316} \times 6$ hari $=38.50$ item

Dengan demikian, pemesanan kembali yaitu pada kondisi tingkat persediaan pengaman ditambah kuantitas pemesanan pada tingkat EOQ yaitu sebesar $38.50+39.83$ $=78$ item. Selanjutnya menghitung reoder point $(\mathrm{ROP})$ yaitu titik jumlah pemesanan kembali atau untuk menentukan berapa batas minimal tingkat persediaan yang harus dipertimbangkan sehingga tidak terjadi kekurangan.

$\mathrm{ROP}=\mathrm{SS}+(\mathrm{d} \times \mathrm{LT})$

$\mathrm{d}=\frac{2028}{316}=6.41$

Maka, ROP $=6.41+(6.41 \times 6)=44.87$ item

Artinya, RSUD Kota Dumai Instansi Logistik harus melakukan pemesanan plastik sedang pada waktu jumlah persediaan logistik tinggal 45 item. Selanjutnya perhitungan untuk maksimum stok adalah sebagai berikut:

Maksimum stok $=\mathrm{EOQ}+\mathrm{SS}+\mathrm{z}$

$\mathrm{z}$ didapat dari kebutuhan selama lead time yaitu:

$\mathrm{z}=\mathrm{LT} \times \frac{\mathrm{D}}{12}=6 \times \frac{2028}{12}=1014$ item

Maka, maksimum stok $=39.83+6.41+1014=1060$ item

Dapat diketahui bahwa jumlah estimasi kebutuhan plastik sedang untuk satu tahun ke depan adalah 2028 item, jumlah maksimum stok sebesar 1060 item, dilakukan pemesanan kembali pada saat jumlah kebutuhan plastik sedang di RSUD Kota Dumai sebanyak 45 item, dan jumlah safety stock sebesar 6 item dengan lead time 6 hari.

4. Tisu Gulung Biasa

Hasil peramalan menggunakan model forecast pemulusan eksponensial untuk bulan Mei 2021 sebesar 180 item. Maka jumlah estimasi kebutuhan jumlah tisu gulung biasa untuk 1 tahun ke depan adalah $180 \times 12=2160$ item.

a. Biaya Pembelian (Purchasing Cost/ Tahun $)=\sum$ Kebutuhan $/$ tahun $\mathrm{x}$ Harga

$$
=2160 \times \text { Rp. } 4000=8.640 .000
$$

b. Biaya Simpan/Unit $($ Nilai h) $=$ Harga Item/Unit x $20 \%=$ Rp. $4000 \times 20 \%$

$$
=\operatorname{Rp} .800
$$

Nilai k masing-masing Item $=$ Konstanta nilai $\mathrm{x}$ dari total biaya pesan setiap kali pesan c. Nilai k Tisu Gulung Biasa

$$
\begin{gathered}
800=\mathrm{X}+\left(\mathrm{X}^{*} 10 \%\right) \\
=\mathrm{X}+0,1 \mathrm{X} \\
=1.1 \mathrm{X}
\end{gathered}
$$

Rumus : Total Nilai $\mathrm{k}=$ Total Kebutuhan/ Tahun (D) $\mathrm{x}$ Nilai K masing-masing item 
d. Total Nilai Tisu Gulung Biasa

Rumus : Q optimal (EOQ)

e. EOQ Tisu Gulung Biasa

Rumus : Frekuensi Pembelian/Periode

f. Frekuensi pesanan Tisu Gulung Biasa

$$
\begin{aligned}
& =2160 \times 1.1=2376 \\
& =\sqrt{\frac{2 \times D \times k}{h}} \\
& =\sqrt{\frac{2 \times 2160 \times 2376}{800}}=113.27 \text { item } \\
& =\frac{\text { Total } \frac{\text { Kebutuhan }}{\text { thn }}}{\text { Qoptimal (EOQ) }} \\
& =\frac{2160}{113.27}=19.06 \mathrm{kali}
\end{aligned}
$$

Setelah diketahui kuantitas pesanan Q pada tingkat EOQ, melengkapi model ini dibutuhkan penentuan waktu tunggu (lead time) antara waktu pesan sampai barang diterima. Oleh karena itu, perusahaan membutuhkan persediaan pengaman. Besarnya persediaan pengaman bisa ditentukan berdasarkan masa tunggu pesanan melalui persamaan, yaitu:

$\begin{array}{ll}\text { Lead Time }(\text { Waktu Pemesanan }) / \text { Periode } & =\frac{316(\text { hari } \text { ker ja setahun })}{\text { Frekuensi Pembelian }} \\ \text { Lead Time Tisu Gulung Biasa } & =\frac{316}{19.06}=17 \text { hari }\end{array}$ $=\frac{316}{19.06}=17$ hari

Persediaan pengaman $=\frac{2160}{316} \times 17$ hari $=116$ item

Dengan demikian, pemesanan kembali yaitu pada kondisi tingkat persediaan pengaman ditambah kuantitas pemesanan pada tingkat EOQ yaitu sebesar $116+113=$ 229 item. Selanjutnya menghitung reoder point (ROP) yaitu titik jumlah pemesanan kembali atau untuk menentukan berapa batas minimal tingkat persediaan yang harus dipertimbangkan sehingga tidak terjadi kekurangan.

$\mathrm{ROP}=\mathrm{SS}+(\mathrm{d} \times \mathrm{LT})$

$\mathrm{d}=\frac{2160}{316}=6.83$

Maka, $\mathrm{ROP}=6.83+(6.83 \times 17)=123$ item

Artinya, RSUD Kota Dumai Instansi Logistik harus melakukan pemesanan tisu gulung biasa pada waktu jumlah persediaan logistik tinggal 123 item. Selanjutnya perhitungan untuk maksimum stok adalah sebagai berikut:

Maksimum stok $=\mathrm{EOQ}+\mathrm{SS}+\mathrm{z}$

$\mathrm{z}$ didapat dari kebutuhan selama lead time yaitu:

$\mathrm{z}=\mathrm{LT} \times \frac{\mathrm{D}}{12}=17 \times \frac{2160}{12}=3060$ item

Maka, maksimum stok $=113+6.83+3060=3179$ item

Dapat diketahui bahwa jumlah estimasi kebutuhan tisu gulung biasa untuk satu tahun ke depan adalah 2160 item, jumlah maksimum stok sebesar 3179 item, dilakukan pemesanan kembali pada saat jumlah kebutuhan tisu gulung biasa di RSUD Kota Dumai sebanyak 123 item, dan jumlah safety stock sebesar 6 item dengan lead time 17 hari.

5. Tisu Hand Towel

Hasil peramalan menggunakan model forecast pemulusan eksponensial untuk bulan Mei 2021 sebesar 92 item. Maka jumlah estimasi kebutuhan jumlah tisu hand towel untuk 1 tahun ke depan adalah $92 \times 12=1014$ item.

a. Biaya Pembelian (Purchasing Cost/ Tahun $)=\sum$ Kebutuhan $/$ tahun $\mathrm{x}$ Harga

$$
=1014 \text { x Rp. } 25.000=25.350 .000
$$


b. Biaya Simpan/Unit $($ Nilai h) $=$ Harga Item/Unit x $20 \%=$ Rp. $25.000 \times 20 \%$

$$
=\text { Rp. } 5000
$$

Nilai $\mathrm{k}$ masing-masing Item $=$ Konstanta nilai $\mathrm{x}$ dari total biaya pesan setiap kali pesan

$$
\text { c. Nilai k Tisu Hand Towel } \quad \begin{aligned}
5000 & =\mathrm{X}+(\mathrm{X} * 10 \%) \\
& =\mathrm{X}+0,1 \mathrm{X} \\
& =1.1 \mathrm{X}
\end{aligned}
$$

Rumus : Total Nilai $\mathrm{k}=$ Total Kebutuhan/ Tahun (D) x Nilai K masing-masing item

d. Total Nilai Tisu Hand Towel

Rumus : Q optimal (EOQ)

e. EOQ Tisu Hand Towel

Rumus : Frekuensi Pembelian/Periode

f. Frekuensi pesanan Tisu Hand Towel

$$
\begin{aligned}
& =5000 \times 1.1=5500 \\
& =\sqrt{\frac{2 \times D X k}{h}} \\
& =\sqrt{\frac{2 \times 5000 \times 5500}{5000}}=104.8 \text { item } \\
& =\frac{\text { Total } \frac{\text { Kebutuhan }}{\text { thn }}}{\text { Qoptimal }(\text { EOQ) }} \\
& =\frac{5000}{104.8}=47.70 \mathrm{kali}
\end{aligned}
$$

Setelah diketahui kuantitas pesanan Q pada tingkat EOQ, melengkapi model ini dibutuhkan penentuan waktu tunggu (lead time) antara waktu pesan sampai barang diterima. Oleh karena itu, perusahaan membutuhkan persediaan pengaman. Besarnya persediaan pengaman bisa ditentukan berdasarkan masa tunggu pesanan melalui persamaan, yaitu:

$\begin{array}{ll}\text { Lead Time }(\text { Waktu Pemesanan }) / \text { Periode } & =\frac{316(\text { hari } \text { kerja setahun })}{\text { Frekuensi } \text { Pembelian }} \\ \text { Lead Time Tisu Hand Towel } & =\frac{316}{47.70}=7 \text { hari }\end{array}$

Persediaan pengaman $=\frac{5000}{316} \times 7$ hari $=111$ item

Dengan demikian, pemesanan kembali yaitu pada kondisi tingkat persediaan pengaman ditambah kuantitas pemesanan pada tingkat EOQ yaitu sebesar $111+105=$ 216 item. Selanjutnya menghitung reoder point (ROP) yaitu titik jumlah pemesanan kembali atau untuk menentukan berapa batas minimal tingkat persediaan yang harus dipertimbangkan sehingga tidak terjadi kekurangan.

$\mathrm{ROP}=\mathrm{SS}+(\mathrm{d} \times \mathrm{LT})$

$\mathrm{d}=\frac{5000}{316}=15.8$

Maka, $\mathrm{ROP}=15.8+(15.8 \times 7)=126$ item

Artinya, RSUD Kota Dumai Instansi Logistik harus melakukan pemesanan hand soap refill pada waktu jumlah persediaan logistik tinggal 126 item. Selanjutnya perhitungan untuk maksimum stok adalah sebagai berikut:

Maksimum stok $=\mathrm{EOQ}+\mathrm{SS}+\mathrm{z}$

$\mathrm{z}$ didapat dari kebutuhan selama lead time yaitu:

$\mathrm{z}=$ LT $\mathrm{x} \frac{\mathrm{D}}{12}=7 \times \frac{5000}{12}=2917$ item

Maka, maksimum stok $=105+15.8+2917=3037$ item

Dapat diketahui bahwa jumlah estimasi kebutuhan tisu hand towel untuk satu tahun ke depan adalah 5000 item, jumlah maksimum stok sebesar 3037 item, dilakukan 
pemesanan kembali pada saat jumlah kebutuhan tisu hand towel di RSUD Kota Dumai sebanyak 126 item, dan jumlah safety stock sebesar 16 item dengan lead time 7 hari.

\section{Kesimpulan}

Adapun kesimpulan dalam penelitian ini adalah Peramalan yang dipilih adalah metode exponential smoothing menggunakan pemulusan konstanta $\alpha=0,2$. Nilai peramalan untuk Hand Soap Refill pada bulan Juni 2021 adalah 162 item. Nilai peramalan untuk Rumah Pisau Cukur pada bulan Juni 2021 adalah 68 item. Nilai peramalan untuk Plastik Sedang pada bulan Juni 2021 adalah 169 item. Nilai peramalan untuk Tisu Gulung Biasa pada bulan Juni 2021 adalah 180 item. Nilai peramalan untuk Tisu Hand Towel pada bulan Juni 2021 adalah 92item dan pihak RSUD Kota Dumai diharapkan bisa menggunakan metode Eqonomic Order Quantity (EOQ) pada manajemen persedian barang rumah tangga (BRT) karena dapat meningkatkan efesiensi penyedian baerang rumah tangga agar tidak terjadinya stock out pada barang atau item yang sering digunakan user dan melakukan pemesanan tepat waktu.

\section{Daftar Pustaka}

Fahmi Sulaiaman, Nanda, 2015, Pengendalian Persedian Bahan Baku Menggunakan Metode EOQ pada UD. Adi Mabel, Politeknik LP3I Medan 2015, ISSN: 2355$701 X$.

Fitra., Khairani, M., dan Indrawan, S., 2020, Perencanaan Persediaan Bahan Bakar Minyak PT X, JURNAL UNITEK, 12(1), 1-9.

Gilang Kencana Gita, 2014, Analisis Perencanaan dan Pengrndalian Persedian Obat Antibiotik RSUD CicalengkaTahun 2014

Indroprasto, Erna Suryani, 2012, Analisis Pengendalian Persedian Produk dengan Metode EOQ menggunakan Algoritma Genetika untuk Mengefisiensikan Biaya Persedian, InstitutTeknologiSepuluh November (ITS) 2012, ISSN: 2301-9271

Ismiarti, Samsulalam, Haerudin, 2017, AnalisisSistem Pengendalian Logistik Barang Non Medik di Rumah Sakit Umum Lasinrang Kab. Pinrang, Pasca Sarjana UMI Makasar 2017, ISSN: 2302-1721

Jessica Juventia, Lusia P.S Hartanti, 2016, Analisis Persedian Bahan Baku PT. BS dengan Metode Economic Order Point (EOQ), Universitas Pelita Harapan Surabaya 2016, Jurnal GEMA AKTUALITA, Vol. 5 No. 1, Juni 2016

Kaekang, Rio A, NangoySientje, 2016, Analisis Logistik (StudiKasusPada PT. Remenia Satori Tepas-Kots Manado)

Keputusan Menteri Kesehatan RI Nomor : 983/Menkes/SK/XI/1992

Mesra, T., Melliana, dan Sitorus, A.A., (2021), Perencanaan Persedian Argon Di Cv Cahaya Teknik Abadi Jurnal ARTI (Aplikasi Rancangan Teknik Industri), VOL.16 NO 1 (2021) Desember 2020 - Mei 2021, Hal: 72-78

Mesra, T., Fitra, dan Anggraini, R., Pengendalian Persediaan Bahan Pendukung Pemurnian Minyak Sawit di PT XYZ, Buletin Utama Teknik, Volume 15 No. 1, Bulan September.

Peraturan Menteri KesehatanNomor 1596/Menkes/per/II/1988

Stephanus Bimata Dyatmika, P. Didit Krisnadewara 2017, Pengendalian Persedian Obat Generik dengan Metode Analisis ABC, Metode EOQ dan Reorder Point (ROP) di Apotek XYZ tahun 2017, Universitas Atma Jaya Yogyakarta 2017, ISSN: 08521875

R. Terry George, Planning-Organizing-Actuating-Controlin (POAC). 
